\title{
Annual Change Report 2003/2004
}

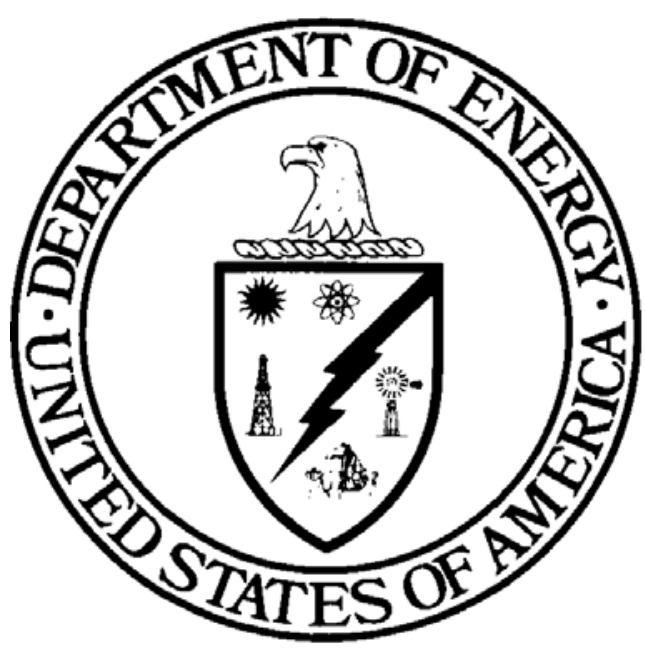

November 10, 2004

United States Department of Energy Waste Isolation Pilot Plant

Carlsbad Field Office

Carlsbad, New Mexico 


\title{
Annual Change Report 2003/2004
}

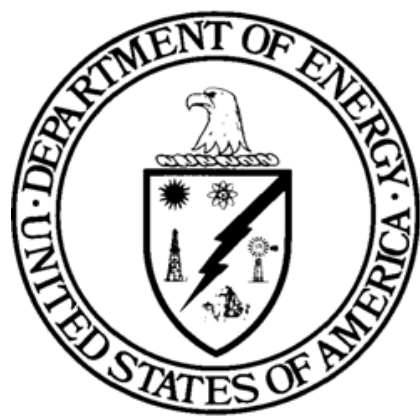

November 10, 2004

\section{United States Department of Energy Waste Isolation Pilot Plant}

\section{Carlsbad Field Office Carlsbad, New Mexico}

\author{
Prepared for: \\ The Department of Energy \\ Prepared by: \\ Washington Regulatory and Environmental Services \\ an affiliate of \\ Washington TRU Solutions, LLC
}




\section{Table of Contents}

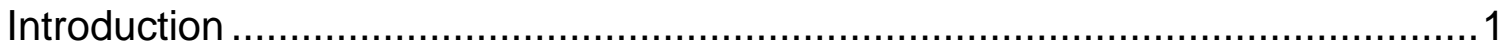

Table 1: Changes in WIPP Conditions or Activities Reportable under 40 CFR

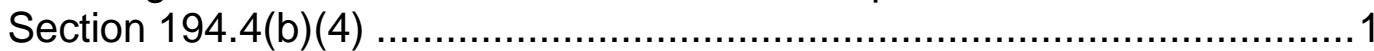

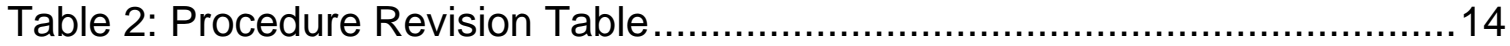

Table 3: Waste Emplacement Summary Report ............................................20

Table 4: Performance Assessment Software and Hardware Changes ...............22

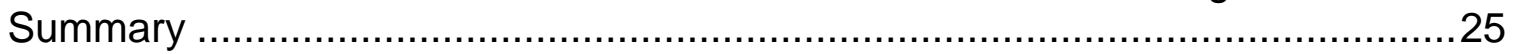

Reports Referenced in and Provided with this Report ...................................25 


\section{Introduction}

As part of continuing compliance, the U.S. Environmental Protection Agency (EPA) requires the U.S. Department of Energy (DOE) to provide any change in information since the most recent compliance application. This requirement is identified in Title 40 Code of Federal Regulations (CFR), Section 194.4(b)(4), which states:

"No later than six months after the administrator issues a certification, and at least annually thereafter, the Department shall report to the Administrator, in writing, any changes in conditions or activities pertaining to the disposal system that were not required to be reported by paragraph (b)(3) of this section and that differ from information contained in the most recent compliance application."

In meeting the requirement, the DOE provides an annual report of all changes applicable under the above requirement each November. This annual report informs the EPA of changes to information in the most recent compliance application, or for this report the 1996 Compliance Certification Application (CCA). Significant planned changes must be reported to the EPA prior to implementation by the DOE. In addition, Title 40 CFR, Section 194.4(b)(3) requires that significant unplanned changes be reported to the EPA within 24 hours or ten days, depending on the severity of the activity or condition. To date, there have been no significant unplanned changes to the certification basis. Planned changes have been submitted on an individual basis. All other changes are reported annually.

The period covered by this Annual Change Report includes changes that occurred between July 1, 2003, and June 30, 2004.

Changes in activities or conditions are reviewed to determine if 40 CFR Section 194.4(b)(3) reporting is necessary. As indicated above, no significant unplanned changes were identified for the time period covered by this report. The enclosed tables list those items identified for reporting under 40 CFR Section 194.4(b)(4). The majority of the changes described in this report are associated with modifications to written plans and procedures for WIPP operations.

This report captures the summary of each change within four tables:

1. "Table 1: Changes in WIPP Conditions or Activities Reportable under Title 40 CFR Section 194.4(b)(4)"

2. "Table 2: Procedure Revision Table" documents changes to relevant plans and procedures during the reporting period

3. "Table 3: Waste Emplacement Summary Report" documents the TRU waste inventory for the waste parameters identified in Table 4-10 of the CCA. The summary provides the total emplaced inventory in the repository as of June 30, 2004 and the inventory that was emplaced during the reporting period (July 1, 2003 to June 30, 2004)

4. "Table 4: SNL (Sandia National Laboratories) Software and Hardware Changes" documents the changes to relevant codes, software and hardware that have occurred during the reporting period

In accordance with the EPA's requests and feedback over the past six years, this annual change report incorporates many of the suggestions and guidance for capturing the appropriate level of detail and the layout of information with respect to the WIPP certification criteria. 
Additional guidance from EPA for this report is included in the letters approving previous annual change reports.

The letter approving the 1999 Annual Change Report (Docket A-98-49, II B-3, Item 11) provides the following guidance:

- "We appreciate your advance notice of the planned changes under 40 CFR Section 194.4(b)(4) that are currently being considered and may be implemented in the near future."

The letter approving the 2000 Annual Change Report (Docket A-98-49, II B-3, Item 26) provides the following guidance:

- "We were pleased that you reported changes that we reviewed and approved during the reporting year, specifically, the elimination of magnesium oxide minisacks and the raising of the repository horizon. This type of reporting is consistent with our December 2000 recertification guidance and should be continued."

The letter approving the 2001 Annual Change Report (Docket A-98-49, II B-3, Item 32) provides the following guidance:

- $\quad$ "CBFO to provide details related to the quantities of all radionuclides and other limited components (that is, those waste components the emplacement of which in the repository is specifically limited by the certification) actually disposed of at the WIPP." Because the list of trace radionuclides has grown so long, DOE is providing only the information for the ten radionuclides included in Table 4-10 of the CCA.

- "List only approvals for the purpose of expanding CBFO's certification of transuranic waste sites to include new equipment, processes, or waste streams. You do not need to list routine quality assurance inspections that do not result in an expansion of CBFO Certification."

- $\quad$ "Send future change reports in PDF format (Adobe files) and one paper copy, so that we can easily include them in our public dockets."

This annual change report has followed the above recommendations for reporting and transmitting the documents. It does not include all administrative changes to procedures. Examples of administrative changes to procedures that were not included are editorial changes, reformatting, correcting the title of references, correcting inconsistency within a procedure, and other changes that do not change the substance or intent of the document.

Also requested was the identification of any references previously entered into the EPA Docket system. This change is visible within the information in Table 1. Applicable references identify the EPA Docket Item Number for the specific information and add a general sentence identifying the change. 
Table 1: Changes in WIPP Conditions or Activities Reportable under Title 40 CFR Section 194.4(b)(4)

July 1, 2003 through June 30, 2004 
Table 1: Changes in WIPP Conditions or Activities Reportable under Title 40 CFR Section 194.4(b)(4) July 1, 2003 through June 30, 2004

\begin{tabular}{|c|c|c|}
\hline $\begin{array}{c}\text { Regulatory } \\
\text { Requirements }\end{array}$ & $\begin{array}{l}\text { Implementing } \\
\text { Document or } \\
\text { Activity that } \\
\text { Changed }\end{array}$ & $\begin{array}{c}\text { Description of the Change and DOE Assessment of the Impact of the } \\
\text { Change }\end{array}$ \\
\hline $\begin{array}{l}\text { 194.14(b) Design of } \\
\text { the disposal system }\end{array}$ & $\begin{array}{l}\text { Status of experiments } \\
\text { in the WIPP } \\
\text { underground }\end{array}$ & $\begin{array}{l}\text { SEGA and MEGA } \\
\text { A modular building for housing the SEGA and MEGA experiment was assembled in the } \\
\text { Room Q Alcove. Collaborating scientists have visited the project and are preparing the } \\
\text { Building for installation of equipment. A trial run for one to two weeks will be conducted in } \\
2004 \text {. Actual operation of the experiment is projected to start in the spring of } 2005 \text {. } \\
\text { EXO } \\
\text { EPA approved Phase I of EXO on February 4, 2004. Preparations continue off-site with no } \\
\text { physical activity on-site to date. }\end{array}$ \\
\hline $\begin{array}{l}\text { 194.14(b) Design of } \\
\text { the disposal system }\end{array}$ & $\begin{array}{l}\text { Table 2: Procedure } \\
\text { Revision Table }\end{array}$ & $\begin{array}{l}\text { The changes to Sandia National Laboratories' (SNL) program documents listed in Table } 2 \\
\text { were minor changes and improvements to the program during this reporting period. } \\
\text { The changes to the WIPP Waste Information System (WWIS) program documents listed in } \\
\text { Table } 2 \text { were minor changes and improvements to the WWIS Program during this reporting } \\
\text { period. } \\
\text { The changes to WIPP Washington TRU Solutions (WTS) plans and procedures listed in } \\
\text { Table } 2 \text { were minor changes and improvements to the program during this reporting period. }\end{array}$ \\
\hline $\begin{array}{l}194.15 \text { (a) Content } \\
\text { of compliance re- } \\
\text { certification } \\
\text { application }\end{array}$ & $\begin{array}{l}\text { Documentation of } \\
\text { continued compliance } \\
\text { pursuant to section 8(f) } \\
\text { of the WIPP Land } \\
\text { Withdrawal Act }\end{array}$ & $\begin{array}{l}\text { The Compliance Recertification Application (CRA) and appropriate references were } \\
\text { submitted in hard copy and on compact disk to the EPA on March 26, 2004. [Docket A-98- } \\
49, \text { II-B4] }\end{array}$ \\
\hline
\end{tabular}


Table 1: Changes in WIPP Conditions or Activities Reportable under Title 40 CFR Section 194.4(b)(4) July 1, 2003 through June 30, 2004

\begin{tabular}{|c|c|c|}
\hline $\begin{array}{l}\text { Regulatory } \\
\text { Requirements }\end{array}$ & $\begin{array}{l}\text { Implementing } \\
\text { Document or } \\
\text { Activity that } \\
\text { Changed }\end{array}$ & $\begin{array}{l}\text { Description of the Change and DOE Assessment of the Impact of the } \\
\text { Change }\end{array}$ \\
\hline 194.21 Inspections & $\begin{array}{l}\text { Inspection of } \\
\text { Washington TRU } \\
\text { Solutions (WTS) } \\
\text { Quality Assurance } \\
\text { Program }\end{array}$ & $\begin{array}{l}\text { The EPA conducted an audit from August 5-6, 2003, of the Washington TRU Solutions } \\
\text { Quality Assurance (QA) program. Letter dated September 11, 2003. [Docket A-98-49, II-A1- } \\
\text { 50] }\end{array}$ \\
\hline 194.21 Inspections & $\begin{array}{l}\text { Inspection of WIPP } \\
\text { Waste Information } \\
\text { System }\end{array}$ & $\begin{array}{l}\text { EPA inspection number EPA-CBFO-WWIS-01.04-24 was conducted January 13-15, } 2004 . \\
\text { Letter dated March 4, 2004. [Docket A-98-49, II-A4-39] }\end{array}$ \\
\hline 194.21 Inspections & $\begin{array}{l}\text { Inspection of Subpart } \\
\text { A, waste emplacement } \\
\text { and parameter } \\
\text { monitoring at WIPP }\end{array}$ & $\begin{array}{l}\text { EPA inspection for EPA-WIPP-6.03-17a (Subpart A), EPA-WIPP-6.03-17b (waste } \\
\text { emplacement), and EPA-WIPP-6.03-17c (parameter monitoring). These inspections were } \\
\text { conducted on June 17-18, 2003. Letter dated 10/22/2003. [Docket A-98-49, II-B3-53] } \\
\text { EPA inspection for EPA-WIPP-6.04-28a (Subpart A), EPA-WIPP-6.04-28b (waste } \\
\text { emplacement), and EPA-WIPP-6.04-28c (parameter monitoring). These inspections were } \\
\text { performed the week of June 28, 2004. }\end{array}$ \\
\hline 194.21 Inspections & $\begin{array}{l}\text { Audit of the Quality } \\
\text { Assurance Programs } \\
\text { at CBFO, CCP, and } \\
\text { SNL }\end{array}$ & $\begin{array}{l}\text { EPA conducted an audit December 2-4, } 2003 \text { of the Quality Assurance (QA) programs of } \\
\text { Carlsbad Field Office (CBFO), the Central Characterization Project (CCP), and SNL. Letter } \\
\text { dated March 9, 2004. [Docket A-98-49, II-A1-57] }\end{array}$ \\
\hline 194.21 Inspections & $\begin{array}{l}\text { Audit of the SNL } \\
\text { Quality Assurance } \\
\text { Program }\end{array}$ & $\begin{array}{l}\text { EPA conducted a follow-up audit during May 28-29, 2003, of SNL's QA program and found } \\
\text { that two previous issues are in conformance with EPA requirements. Letter dated August } \\
23,2003 \text {. [Docket A-98-49, II-A1-49] } \\
\text { EPA audited the SNL QA program on February 24-26, 2004. Letter dated April 19, } 2004 . \\
\text { [Docket A-98-49, II-A1-59] }\end{array}$ \\
\hline $\begin{array}{l}\text { 194.22(a) Quality } \\
\text { assurance }\end{array}$ & $\begin{array}{l}\text { WWIS computer } \\
\text { hardware changes }\end{array}$ & $\begin{array}{l}\text { On June } 15,2004 \text {, the WWIS database was moved from DEC Alpha computers to Sun } \\
\text { Solaris systems to improve reliability. }\end{array}$ \\
\hline
\end{tabular}


Table 1: Changes in WIPP Conditions or Activities Reportable under Title 40 CFR Section 194.4(b)(4) July 1, 2003 through June 30, 2004

\begin{tabular}{|c|c|c|}
\hline $\begin{array}{l}\text { Regulatory } \\
\text { Requirements }\end{array}$ & $\begin{array}{c}\text { Implementing } \\
\text { Document or } \\
\text { Activity that } \\
\text { Changed }\end{array}$ & $\begin{array}{c}\text { Description of the Change and DOE Assessment of the Impact of the } \\
\text { Change }\end{array}$ \\
\hline $\begin{array}{l}\text { 194.22(a) Quality } \\
\text { assurance }\end{array}$ & $\begin{array}{l}\text { Waste Generator Site - } \\
\text { Hanford }\end{array}$ & $\begin{array}{l}\text { EPA audit of the Hanford Site's QA Program conducted June 17-19, 2003, determined that } \\
\text { "TRU wastes that were characterized after January 1, 2003, shall not be shipped to the } \\
\text { WIPP until EPA verifies corrective actions at the Hanford Site." Letter dated July 21, } 2003 . \\
\text { [Docket A-98-49, II-A1-46] } \\
\text { EPA conducted a follow-up audit of the Hanford Site's QA program from July 29-30, } 2003 \\
\text { that found that Hanford's management had corrected the deficiency found in the previous } \\
\text { audit. "Transuranic (TRU) waste that was characterized before February 1, 2003, may be } \\
\text { disposed at the WIPP without additional approvals by the EPA. TRU waste characterized } \\
\text { during the period between February 1, 2003, and July } 31,2003 \text {, using EPA approved waste } \\
\text { characterization (WC) processes may be shipped to WIPP only after EPA is notified and } \\
\text { approves shipment....Waste characterized beginning August 1, 2003, may be disposed at } \\
\text { WIPP without additional approvals by EPA." Letter dated September 12, 2003. [Docket A- } \\
\text { 98-49, II-A1-51] } \\
\text { EPA conducted an audit during September 9-11, } 2003 \text { of the QA program of CCP. Letter } \\
\text { dated March 9, 2004. [Docket A-98-49, II-A1-55] } \\
\text { EPA conducted a second follow-up audit during September 9-11, 2003: "EPA... has } \\
\text { determined that Hanford may ship TRU waste characterized between February 1, 2003, and } \\
\text { July 31, 2003, without any further notification or approval from EPA." Letter dated March 9, } \\
\text { 2004. [Docket A-98-49, II-A1-58] }\end{array}$ \\
\hline
\end{tabular}


Table 1: Changes in WIPP Conditions or Activities Reportable under Title 40 CFR Section 194.4(b)(4) July 1, 2003 through June 30, 2004

\begin{tabular}{|c|c|c|}
\hline $\begin{array}{l}\text { Regulatory } \\
\text { Requirements }\end{array}$ & $\begin{array}{l}\text { Implementing } \\
\text { Document or } \\
\text { Activity that } \\
\text { Changed }\end{array}$ & $\begin{array}{c}\text { Description of the Change and DOE Assessment of the Impact of the } \\
\text { Change }\end{array}$ \\
\hline $\begin{array}{l}\text { 194.22(a) Quality } \\
\text { assurance }\end{array}$ & $\begin{array}{l}\text { Waste Generator Site - } \\
\text { Idaho National } \\
\text { Engineering and } \\
\text { Environmental } \\
\text { Laboratory (INEEL) }\end{array}$ & $\begin{array}{l}\text { EPA conducted an audit from August 19-21, 2003, of the quality assurance program of the } \\
\text { Advanced Mixed Waste Treatment Project (AMWTP) at INEEL. EPA conducted another } \\
\text { audit from October 15-16, 2003, to verify completion of corrective actions and to expand the } \\
\text { size of the audit sample. Based on the results of the follow-up audit, EPA will make a final } \\
\text { determination regarding full compliance in that inspection report. Letter dated January 30, } \\
\text { 2004. [Docket A-98-49, II-A1-53] } \\
\text { EPA conducted the follow-up audit of the quality assurance (QA) program of AMWTP at } \\
\text { INEEL and approved the QA program. Letter dated March 9, } 2004 \text { [Docket A-98-49, II-A1- } \\
\text { 56] }\end{array}$ \\
\hline $\begin{array}{l}194.23 \text { Models and } \\
\text { computer codes }\end{array}$ & $\begin{array}{l}\text { Table 4: Performance } \\
\text { Assessment (PA) } \\
\text { Software and } \\
\text { Hardware Changes }\end{array}$ & $\begin{array}{l}\text { The changes to PA software and hardware have been compiled and are located in Table } 4 \\
\text { and were minor changes and improvements to the program during this reporting period. }\end{array}$ \\
\hline $\begin{array}{l}\text { 194.24(b) Waste } \\
\text { characterization }\end{array}$ & $\begin{array}{l}\text { AMWTF compressed } \\
\text { (super-compacted) } \\
\text { waste }\end{array}$ & $\begin{array}{l}\text { On March 26, 2004, EPA approved disposal of compressed (super-compacted) waste at } \\
\text { WIPP with the requirement to place additional magnesium oxide (MgO) with the } \\
\text { compressed waste to maintain a } 1.67 \text { safety factor. [Docket A-98-49 II-B3-68] }\end{array}$ \\
\hline $\begin{array}{l}\text { 194.24(c) Waste } \\
\text { characterization }\end{array}$ & $\begin{array}{l}\text { CCA Appendix WAP- } \\
\text { Waste Analysis Plan }\end{array}$ & $\begin{array}{l}\text { The Waste Analysis Plan (WAP) specifies acceptable sampling and analysis techniques } \\
\text { and establishes data quality objectives for characterization of CH TRU mixed waste. } \\
\text { On March 15, 2004, NMED approved a Class } 2 \text { permit modification to allow receipt of Los } \\
\text { Alamos National Laboratory (LANL) Sealed Sources without headspace gas sampling } \\
\text { analysis when additional acceptable knowledge documentation requirements necessary to } \\
\text { identify hazardous constituents are present. } \\
\text { On May 7, 2004, NMED approved a Class } 2 \text { permit modification to allow packaging-specific } \\
\text { Drum Age Criteria for New Approved Waste Containers without rigid polyliners. }\end{array}$ \\
\hline
\end{tabular}


Table 1: Changes in WIPP Conditions or Activities Reportable under Title 40 CFR Section 194.4(b)(4) July 1, 2003 through June 30, 2004

\begin{tabular}{|c|c|c|}
\hline $\begin{array}{l}\text { Regulatory } \\
\text { Requirements }\end{array}$ & $\begin{array}{l}\text { Implementing } \\
\text { Document or } \\
\text { Activity that } \\
\text { Changed }\end{array}$ & $\begin{array}{c}\text { Description of the Change and DOE Assessment of the Impact of the } \\
\text { Change }\end{array}$ \\
\hline $\begin{array}{l}\text { 194.24(c) Waste } \\
\text { characterization }\end{array}$ & $\begin{array}{l}\text { CH-WAC, Contact } \\
\text { Handled Waste } \\
\text { Acceptance Criteria }\end{array}$ & $\begin{array}{l}\text { The Contact-Handled Waste Acceptance Criteria (CH-WAC) summarizes the waste } \\
\text { acceptance criteria applicable to the transportation, storage, and disposal of transuranic } \\
\text { (CH-TRU) waste at WIPP. } \\
\text { Changes in the CH-WAC during the reporting period were as follows: } \\
\text { On March 1, } 2004 \text { DOE completed a revision of the CH-WAC (DOE/WIPP-02-3122 } \\
\text { Revision 1) that authorizes the use of the HalfPACT shipping package, changes the } \\
\text { fissile gram equivalent limits for shipping, and adds text to Appendix A for consistency with } \\
\text { regard to document review, approval, and implementation. }\end{array}$ \\
\hline $\begin{array}{l}194.24(\mathrm{c}) \text { Waste } \\
\text { characterization } \\
\text { and Appendix A to } \\
\text { Part 194, conditions } \\
2 \text { and 3 }\end{array}$ & $\begin{array}{l}\text { Waste Generator Site } \\
\text { Certification } \\
\text { Argonne National } \\
\text { Laboratory-East } \\
(\text { (ANL-E) }\end{array}$ & $\begin{array}{l}\text { EPA inspection number EPA-ANL-E-CCP-11-03.24. "The ANL-E is approved to dispose at } \\
\text { the WIPP the contact-handled transuranic solid waste (S3000) characterized by CCP. " } \\
\text { dated January 5, } 2004 \text { [Docket A-98-49, II-A4-37] } \\
\text { CBFO memorandum, "Expansion of Characterization and Certification Authority for Central } \\
\text { Characterization Project at Argonne National Laboratory - East to Include Homogeneous } \\
\text { Solids (S3000)," dated June 4, 2004. }\end{array}$ \\
\hline
\end{tabular}


Table 1: Changes in WIPP Conditions or Activities Reportable under Title 40 CFR Section 194.4(b)(4) July 1, 2003 through June 30, 2004

\begin{tabular}{|c|c|c|}
\hline $\begin{array}{l}\text { Regulatory } \\
\text { Requirements }\end{array}$ & $\begin{array}{l}\text { Implementing } \\
\text { Document or } \\
\text { Activity that } \\
\text { Changed }\end{array}$ & $\begin{array}{c}\text { Description of the Change and DOE Assessment of the Impact of the } \\
\text { Change }\end{array}$ \\
\hline $\begin{array}{l}194.24(\mathrm{c}) \text { Waste } \\
\text { characterization } \\
\text { and Appendix A to } \\
\text { Part 194, conditions } \\
2 \text { and } 3\end{array}$ & $\begin{array}{l}\text { Waste Generator Site - } \\
\text { Hanford }\end{array}$ & $\begin{array}{l}\text { EPA inspection number EPA-Hanford-06-03.8 and } 24 \text { approved waste characterization } \\
\text { activities at Hanford. "The DOE is approved to dispose at the WIPP TRU debris waste } \\
\text { characterized at Hanford's Waste Receiving and Processing Plant and Plutonium Finishing } \\
\text { Plant using the approved systems and processes in the accompanying report." Letter dated } \\
\text { August 7, 2003. [Docket A-98-49, II-A4-32] } \\
\text { EPA conducted a follow-up audit on September 10, } 2003 \text { (Inspection EPA-Hanford-06- } \\
\text { 03.24) to evaluate the additional calorimeters. "We approve these six calorimeters..." Letter } \\
\text { dated October 23, 2003. [Docket A-98-49, II-A4-33] } \\
\text { CBFO memorandum, "Annual Re-Evaluation of Hanford Site TRU Waste Program } \\
\text { Compliance and Expansion to Include New Nondestructive Assay Systems," dated } \\
\text { December 9, 2003. } \\
\text { EPA inspection number EPA-Hanford-CCP-09.03-8 was conducted September 8-12, } 2003 . \\
\text { Letter dated February 23, 2004. [Docket A-98-49, II-A4-38] } \\
\text { "With this letter, we confirm that our previous approval of calorimeters at Hanford for waste } \\
\text { characterization can be extended to the use of the aforementioned calorimeters using the } \\
\text { methods detailed..." Letter dated March 26, 2004. [Docket A-98-49, II-A4-41] }\end{array}$ \\
\hline
\end{tabular}


Table 1: Changes in WIPP Conditions or Activities Reportable under Title 40 CFR Section 194.4(b)(4) July 1, 2003 through June 30, 2004

\begin{tabular}{|l|l|l|}
\hline \multicolumn{1}{|c|}{$\begin{array}{c}\text { Regulatory } \\
\text { Requirements }\end{array}$} & $\begin{array}{c}\text { Implementing } \\
\text { Document or } \\
\text { Activity that } \\
\text { Changed }\end{array}$ & \multicolumn{1}{|c|}{$\begin{array}{c}\text { Description of the Change and DOE Assessment of the Impact of the } \\
\text { Change }\end{array}$} \\
\hline $\begin{array}{l}\text { 194.24(c) Waste } \\
\text { characterization } \\
\text { and Appendix A to } \\
\text { Part 194, conditions } \\
2 \text { and 3 }\end{array}$ & $\begin{array}{l}\text { Waste Generator Site - } \\
\text { INEEL }\end{array}$ & $\begin{array}{l}\text { CBFO memorandum, "Certification of INEEL TWCP." Based on the results of audit A-03-15, } \\
\text { the CBFO is granting INEEL TRU Waste Characterization Program (TWCP) authority for } \\
\text { characterization and data generation level review, validation, and verification of data for } \\
\text { S5000 and S3000 Summary Categories using the listed characterization methods. Letter } \\
\text { dated November 25, 2003. }\end{array}$ \\
& $\begin{array}{l}\text { EPA inspections EPA-INEEL-AMWTP-8-03.08 and EPA-INEEL-AMWTP-10-03.24 of the } \\
\text { AMWTP determined that the use of the non-destructive assay (NDA) systems and } \\
\text { processes included in the inspection were adequate for TRU solid waste with measured } \\
\text { TRU activity above the lower detection limits. Letter dated January 30, 2004. [Docket A-98- } \\
\text { 49, II-A4-36] }\end{array}$ \\
& $\begin{array}{l}\text { EPA letter approved retrievably-stored, CH solid waste characterized using the approved } \\
\text { systems and processes of the AMWTP for disposal at WIPP. Letter dated March 8, 2004. } \\
\text { CBFO memorandum, "Authority Granted to INEEL AMWTP for Characterization and } \\
\text { certification of Contact Handled Homogeneous Solids Transuranic Waste." Based on the } \\
\text { results of Audit A-03-05, the CBFO is granting authority for characterization, certification } \\
\text { and transportation of homogenous solids waste (S3000). Letter dated March 9, 2004. }\end{array}$ \\
\hline & & \\
& &
\end{tabular}


Table 1: Changes in WIPP Conditions or Activities Reportable under Title 40 CFR Section 194.4(b)(4) July 1, 2003 through June 30, 2004

\begin{tabular}{|l|l|l|}
\hline \multicolumn{1}{|c|}{$\begin{array}{c}\text { Regulatory } \\
\text { Requirements }\end{array}$} & $\begin{array}{l}\text { Implementing } \\
\text { Document or } \\
\text { Activity that } \\
\text { Changed }\end{array}$ & \multicolumn{1}{|c|}{$\begin{array}{c}\text { Description of the Change and DOE Assessment of the Impact of the } \\
\text { Change }\end{array}$} \\
\hline $\begin{array}{l}\text { 194.24(c) Waste } \\
\text { characterization } \\
\text { and Appendix A to } \\
\text { Part 194, conditions } \\
2 \text { and 3 }\end{array}$ & $\begin{array}{l}\text { Waste Generator Site - } \\
\text { Rocky Flats } \\
\text { Environmental } \\
\text { Technology Site }\end{array}$ & $\begin{array}{l}\text { CBFO memorandum, "Annual Re-Certification of Rocky Flats Environmental Technology } \\
\text { TRU Waste Program and Addition of RTR for Lead-Lined Drums and a Third Headspace } \\
\text { Gas Unit," dated September 19, 2003. } \\
\text { EPA inspection number EPA-RFETS-7-03.08 approved applicable waste characterization } \\
\text { activities at RFETS as required under Condition 3 of our certification of WIPP. Letter dated } \\
\text { November 21, 2003. [Docket A-98-49, II-A4-34] } \\
\text { CBFO memorandum, "Expansion of RFETS' TRU Waste Program Certification Authority to } \\
\text { include New Solids Sampling Processes and New NDA Systems, " dated December 30, } \\
\text { 2003. }\end{array}$ \\
\hline $\begin{array}{l}\text { 194.24(c) Waste } \\
\text { characterization } \\
\text { and Appendix A to } \\
\text { Part 194, conditions } \\
\text { 2 and 3 }\end{array}$ & $\begin{array}{l}\text { Waste Generator Site - } \\
\text { Savannah River Site }\end{array}$ & $\begin{array}{l}\text { EPA inspection number EPA SRS-CCP-10-03.24 determined that the previous approval of } \\
\text { the mobile IPAN system (EPA Inspection EPA-CCP-10.01-8) as limited by our August 8, } \\
\text { 2003, letter still applies. Letter dated March 29, 2004. [Docket A-98-49, II A4-40] } \\
\text { CBFO memorandum, "Annual Re-Evaluation of CCP TRU Waste Program at Savannah } \\
\text { River Site and Expansion to include the IQ3 Nondestructive Assay System," dated August } \\
\text { 8, 2003. }\end{array}$ \\
\hline $\begin{array}{l}\text { 194.24(c) Waste } \\
\text { characterization }\end{array}$ & $\begin{array}{l}\text { RH TRU Waste } \\
\text { Characterization } \\
\text { Program } \\
\text { Implementation Plan } \\
\text { and RH TRU Waste } \\
\text { Characterization Plan }\end{array}$ & $\begin{array}{l}\text { On March 26, 2004, EPA approved the RH TRU Waste Characterization Program } \\
\text { Implementation Plan and RH TRU Waste Characterization Plan. This decision does not } \\
\text { authorize any site to begin RH waste characterization or shipment to WIPP. }\end{array}$ \\
\hline
\end{tabular}


Table 1: Changes in WIPP Conditions or Activities Reportable under Title 40 CFR Section 194.4(b)(4) July 1, 2003 through June 30, 2004

\begin{tabular}{|c|c|c|}
\hline $\begin{array}{l}\text { Regulatory } \\
\text { Requirements }\end{array}$ & $\begin{array}{l}\text { Implementing } \\
\text { Document or } \\
\text { Activity that } \\
\text { Changed }\end{array}$ & $\begin{array}{c}\text { Description of the Change and DOE Assessment of the Impact of the } \\
\text { Change }\end{array}$ \\
\hline 194.27 Peer review & $\begin{array}{l}\text { CBFO MP } 10.5 \text { Peer } \\
\text { Review }\end{array}$ & $\begin{array}{l}\text { An independent Spallings Peer Review was held the week of July 7, } 2003 \text { in Albuquerque, } \\
\text { NM. The Peer Review Report was completed in October } 2003 \text {. The panel concluded: } \\
\text { - The new Spallings conceptual model appears generally sound in its structure and } \\
\text { reasonableness. } \\
\text { - The proposed implementation of the new Spallings model appears reasonable. } \\
\text { - Output from sensitivity analysis indicates acceptable results. }\end{array}$ \\
\hline 194.27 Peer review & $\begin{array}{l}\text { CBFO MP } 10.5 \text { Peer } \\
\text { Review }\end{array}$ & $\begin{array}{l}\text { On November 12, 2003, CBFO issued Interim Change Notice \#1, Management Procedure } \\
\text { 10.5, Revision 5, Peer Review: Change paragraph } 7.1 \text { of attachment one to read: "The } \\
\text { CBFO QA Manager should conduct assessments of the peer review process to ensure that } \\
\text { all aspects of the peer review process conform to this procedure." }\end{array}$ \\
\hline $\begin{array}{l}\text { 194.32(c) Scope of } \\
\text { performance } \\
\text { assessments, } \\
194.33 \\
\text { Consideration of } \\
\text { drilling events in } \\
\text { performance } \\
\text { assessments }\end{array}$ & $\begin{array}{l}\text { SNL Annual } \\
\text { Compliance Monitoring } \\
\text { Parameter } \\
\text { Assessment for } 2003\end{array}$ & $\begin{array}{l}\text { SNL issued the SNL Annual Compliance Monitoring Parameter Assessment for } 2003 \text { in } \\
\text { June, 2004. A copy of this report is included with this report. }\end{array}$ \\
\hline 194.42 Monitoring & $\begin{array}{l}\text { Table 3: Waste } \\
\text { Emplacement } \\
\text { Summary Report }\end{array}$ & $\begin{array}{l}\text { A summary of the TRU waste inventory that has been emplaced in the repository is } \\
\text { presented in Table } 3 \text { of this report. The inventory includes volumes and radiological activity } \\
\text { (curie content) of waste that has been emplaced in the repository as of June } 30,2004 \text {. }\end{array}$ \\
\hline 194.42 Monitoring & $\begin{array}{l}\text { Delaware Basin } \\
\text { Monitoring Annual } \\
\text { Report } \\
\text { DOE/WIPP-99-2308 }\end{array}$ & $\begin{array}{l}\text { DOE/WIPP-99-2308, Rev. 4, issued in September 2003. The time period for which this } \\
\text { report is developed is September 01, } 2002 \text { through August 31, 2003. A copy of this report is } \\
\text { included with this report. }\end{array}$ \\
\hline
\end{tabular}


Table 1: Changes in WIPP Conditions or Activities Reportable under Title 40 CFR Section 194.4(b)(4) July 1, 2003 through June 30, 2004

\begin{tabular}{|l|l|l|}
\hline $\begin{array}{c}\text { Regulatory } \\
\text { Requirements }\end{array}$ & $\begin{array}{l}\text { Implementing } \\
\text { Document or } \\
\text { Activity that } \\
\text { Changed }\end{array}$ & \multicolumn{1}{|c|}{$\begin{array}{c}\text { Description of the Change and DOE Assessment of the Impact of the } \\
\text { Change }\end{array}$} \\
\hline 194.42 Monitoring & $\begin{array}{l}\text { WIPP Site } \\
\text { Environmental Report } \\
\text { Calendar Year 2002 } \\
\text { DOE/WIPP 03-2225 }\end{array}$ & $\begin{array}{l}\text { DOE/WIPP 03-2225, WIPP Site Environmental Report for Calendar Year 2002, September } \\
\text { 2003. This report provides information and data on groundwater and meteorological } \\
\text { monitoring. A copy of this report is included with this report. }\end{array}$ \\
\hline 194.42 Monitoring & $\begin{array}{l}\text { WIPP Subsidence } \\
\text { Monument Leveling } \\
\text { Survey } \\
\text { DOE/WIPP-04-2293 }\end{array}$ & $\begin{array}{l}\text { DOE/WIPP-04-2293, WIPP Subsidence Monument Leveling Survey, was issued in October } \\
\text { 2003. Subsidence information obtained from surveys conducted during September 2003, is } \\
\text { included in the report. A copy of this report is included with this report. }\end{array}$ \\
\hline 194.42 Monitoring & $\begin{array}{l}\text { Geotechnical Analysis } \\
\text { Report for July 2002 - } \\
\text { June 2003 } \\
\text { DOE/WIPP 04-3177 }\end{array}$ & $\begin{array}{l}\text { DOE WIPP 04-3177, Geotechnical Analysis Report for July 2002 - June 2003, was issued } \\
\text { in March 2004. A copy of this report is included with this report. }\end{array}$ \\
\hline
\end{tabular}




\section{Table 2: Procedure Revision Table}

\section{July 1, 2003 through June 30, 2004}


Table 2: Procedure Revision Table

\begin{tabular}{|c|c|c|}
\hline Procedure & $\begin{array}{l}\text { Rev. \& Effective } \\
\text { Date }\end{array}$ & Description of Changes from $07 / 01 / 03$ through $6 / 30 / 04$ \\
\hline DOE/CBFO 97-2273 WWIS User's Guide & $\begin{array}{l}\text { Rev. 7, 06/01/04 } \\
\text { Rev. 6, 05/10/04 } \\
\text { Rev. 5, 12/29/03 }\end{array}$ & $\begin{array}{l}\text { The change to the document included a minor update to include a diagram that depicts the } \\
\text { design of WWIS hardware. } \\
\text { The change to the document included a new revision to address WWIS software upgrade to } \\
\text { version } 4.16 \text {. Primarily minor editorial updates and clarifications. } \\
\text { The change to the document included a complete rewrite that included adding new sections to } \\
\text { summarize input or assay methods, characterization methods, automated container data } \\
\text { check/functionality, overpacking, reporting of headspace gas analytical data, and a discussion } \\
\text { about beryllium in quantities }>1 \text { percent by weight and associated transportation limits. }\end{array}$ \\
\hline $\begin{array}{l}\text { Sandia National Laboratories (SNL) } \\
\text { NP 2-1, Qualification and Training }\end{array}$ & Rev. 7, 06/03/04 & $\begin{array}{l}\text { This is a complete revision of NP 2-1. The layout has been rearranged into the following major } \\
\text { sections: Initial Qualification and Training of Individuals, Updated Qualification and Training of } \\
\text { Individuals, Annual WIPP QA Training, and New or Revised Procedure Training. A procedure } \\
\text { matrix has been added that identifies required procedures for individual job categories. Form } \\
\text { NP 2-1-1, Qualification and Training Form, has been updated to reflect the procedures matrix. } \\
\text { A "self study" option is now included on Form NP 2-1-2, Training Record. All flow charts have } \\
\text { been updated. }\end{array}$ \\
\hline $\begin{array}{l}\text { Sandia National Laboratories (SNL) } \\
\text { NP 4-1, Procurement }\end{array}$ & $\begin{array}{l}\text { Rev. } 7,06 / 24 / 04 \\
\text { Rev. } 6,07 / 18 / 03\end{array}$ & $\begin{array}{l}\text { Procedure NP 4-1 was revised to address conditions identified in a Corrective Action Request } \\
\text { (CAR) (CBFO CAR 04-010) from a CBFO audit and a CAR (IS-04-06-CAR-01) from an internal } \\
\text { surveillance. Procedure NP 4-1 has been revised to clarify the procurement and receipt } \\
\text { inspection processes. NP 4-1 has also been changed to remove the Quality Grade levels. } \\
\text { NP 4-1 was revised to delineate the roles and responsibilities of the Procurement function and } \\
\text { Document Control identified as a problem in CAR W-02-10. }\end{array}$ \\
\hline $\begin{array}{l}\text { Sandia National Laboratories (SNL) } \\
\text { NP 12-1, Control of Measuring and Test } \\
\text { Equipment }\end{array}$ & Rev. 4, 07/17/03 & $\begin{array}{l}\text { NP 12-1 was revised to comply with CBFO QAPD Rev. 5. Removed requirements that } \\
\text { calibration services conform to ANSI/NCSL Z540-1. }\end{array}$ \\
\hline
\end{tabular}


Table 2: Procedure Revision Table

\begin{tabular}{|c|c|c|}
\hline Procedure & $\begin{array}{c}\text { Rev. \& Effective } \\
\text { Date }\end{array}$ & Description of Changes from $07 / 01 / 03$ through $6 / 30 / 04$ \\
\hline $\begin{array}{l}\text { Sandia National Laboratories (SNL) } \\
\text { NP } 16-1 \text {, Corrective Action }\end{array}$ & Rev. 4, 09/29/03 & $\begin{array}{l}\text { NP 16-1 description of changes is as follows: Added text on performing a partial verification of } \\
\text { corrective action; consistent use of Corrected During the Audit/Surveillance (CDA/CDS) when } \\
\text { identifying trending of CARs; required level of review for CARs and CAPs. This revision } \\
\text { addressed the use of the partial verification process. }\end{array}$ \\
\hline $\begin{array}{l}\text { Sandia National Laboratories (SNL) } \\
\text { NP } 17-1 \text {, Records }\end{array}$ & $\begin{array}{l}\text { Rev. 5, 05/27/04 } \\
\text { Rev. 4, 07/14/03 }\end{array}$ & $\begin{array}{l}\text { Editorial changes and clarifications made. } \\
\text { Section 2.3, QA review of all submittals was added and editorial changes were made. Changes } \\
\text { were made to the Records Submittal form NP 17-1-2 (Appendix B) to require the signature of } \\
\text { QA reviewer. }\end{array}$ \\
\hline $\begin{array}{l}\text { Sandia National Laboratories (SNL) } \\
\text { NP 18-1, Audits and Surveillances }\end{array}$ & Rev. 5, 09/30/03 & $\begin{array}{l}\text { NP 18-1 was revised to address conditions identified in CAR W-03-09. The reason for this } \\
\text { revision is to add and define terms Corrected During the Audit/Surveillance (CDA/CDS), } \\
\text { Observations and Recommendations to provide more consistency between the SNL } \\
\text { assessment program and the CBFO program. }\end{array}$ \\
\hline $\begin{array}{l}\text { Sandia National Laboratories (SNL) } \\
\text { NP 20-2, Scientific Notebooks }\end{array}$ & $\begin{array}{l}\text { Rev. 4, 05/06/04 } \\
\text { Rev. 3, 07/17/03 }\end{array}$ & $\begin{array}{l}\text { Revision to procedure was to provide clarification and to address the scientific notebook CAR } \\
\text { W-03-12, and in response to the scientific notebook internal surveillance IS 04-03. } \\
\text { Removed a sentence that refers to a PI defining the content of a notebook entry in response to } \\
\text { Observation \#2, Audit IA 02-01. }\end{array}$ \\
\hline $\begin{array}{l}\text { Sandia National Laboratories (SNL) } \\
\text { SP 1-1, QA Grading }\end{array}$ & $\begin{array}{l}\text { Rev. } 5,06 / 24 / 04 \\
\text { Rev. } 4,07 / 18 / 03\end{array}$ & $\begin{array}{l}\text { Procedure SP 1-1 was revised to address conditions identified in a CAR (CBFO CAR 04-010) } \\
\text { from a CBFO audit and a CAR (IS-04-06-CAR-01) from an internal surveillance. Procedure } \\
\text { SP 1-1 has been revised to clarify the grading process by better defining Quality Grade levels } \\
\text { QL-1 and QL-2, and adding more specific criteria for QA Grading levels. } \\
\text { Procedure SP 1-1 was revised to add "Grading" to the title of Form SP 1-1-1 and make the } \\
\text { procedure consistent with NP 4-1, Rev. } 6 \text {. }\end{array}$ \\
\hline
\end{tabular}


Table 2: Procedure Revision Table

\begin{tabular}{|c|c|c|}
\hline Procedure & $\begin{array}{l}\text { Rev. \& Effective } \\
\text { Date }\end{array}$ & Description of Changes from $07 / 01 / 03$ through $6 / 30 / 04$ \\
\hline $\begin{array}{l}\text { Sandia National Laboratories (SNL) } \\
\text { SP 6-1, Publicly Released Documents }\end{array}$ & $\begin{array}{l}\text { Rev. 4, 06/14/04 } \\
\text { Rev. 3, 09/17/03 }\end{array}$ & $\begin{array}{l}\text { Procedure SP 6-1 was revised to incorporate the new SNL electronic Review and Approval } \\
\text { system. The flow chart in Appendix A was updated to reflect the new electronic process. } \\
\text { The Designated Unclassified Subject Area (DUSA) program was incorporated into the } \\
\text { procedure. A DUSA delegate can sign off in Section } 4 \text { of the Review and Approval form. The } \\
\text { requirement for an approval letter from CBFO for the sensitivity review was modified to allow } \\
\text { email notification of approval. Sections } 2.11 \text { "References" and } 2.12 \text { "Forms" were removed to } \\
\text { align the procedure with other SPs. }\end{array}$ \\
\hline $\begin{array}{l}\text { Sandia National Laboratories (SNL) } \\
\text { SP 9-6 Baseline Inventory Report (BIR) } \\
\text { Change Report Data Collection and Entry }\end{array}$ & Rev 2. 03/10/03 & $\begin{array}{l}\text { Procedure SP 9-6 describes the activities performed by LANL and SNL for the development of } \\
\text { an update report to the Transuranic Baseline Inventory Report (TWBIR) in the CCA. The work } \\
\text { was performed under this procedure and under other applicable SNL QA procedures under a } \\
\text { Memorandum of Agreement. This procedure was not reported last year. }\end{array}$ \\
\hline $\begin{array}{l}\text { Washington TRU Solutions (WTS) } \\
\text { 02-EC3506, Environmental Incident } \\
\text { Reporting }\end{array}$ & Rev. 4, 10/02/03 & $\begin{array}{l}\text { Procedure WP EC3506, Environmental Incident Reporting was revised 10/02/03. The changes } \\
\text { were to clarify reporting quantities, to implement changes to receive polychlorinated biphenyl } \\
\text { (PCB) contaminated waste, and minor editorial changes. }\end{array}$ \\
\hline $\begin{array}{l}\text { Washington TRU Solutions (WTS) } \\
\text { 02-EM1007, Cation and Anion Analysis }\end{array}$ & Rev. 1, 09/19/03 & $\begin{array}{l}\text { Procedure WP 02-EM1007, Cation and Anion Analysis was revised 9/19/03 to define the } \\
\text { parameters for the saved analyses and make minor editorial changes. This is part of the } \\
\text { groundwater monitoring program. }\end{array}$ \\
\hline $\begin{array}{l}\text { Washington TRU Solutions (WTS) } \\
\text { 02-PC3003, WTS Compliance } \\
\text { Certification and PCB Change Screening } \\
\text { and Notification of Radionuclide Release } \\
\text { or Potential Release }\end{array}$ & Rev. 3, 09/25.03 & $\begin{array}{l}\text { Procedure WP 02-PC3003, WTS Compliance Certification and PCB Change Screening and } \\
\text { Notification of Radionuclide Release or Potential Release was revised 9/25/03. The changes } \\
\text { were to implement changes to receive PCB contaminated waste, update the document list, and } \\
\text { minor editorial changes. }\end{array}$ \\
\hline $\begin{array}{l}\text { Washington TRU Solutions (WTS) } \\
\text { 05-WH1011, CH Waste Processing }\end{array}$ & Rev. 20, 01/26/04 & $\begin{array}{l}\text { Procedure WP 05-WH1011, CH Waste Processing was revised 01/26/04 to implement changes } \\
\text { to receive PCB contaminated waste and HalfPACT package information, clarify stacking } \\
\text { heights in the Waste Handling Building and the underground, and make minor editorial } \\
\text { changes. }\end{array}$ \\
\hline
\end{tabular}


Table 2: Procedure Revision Table

\begin{tabular}{|c|c|c|}
\hline Procedure & $\begin{array}{c}\text { Rev. \& Effective } \\
\text { Date }\end{array}$ & Description of Changes from $07 / 01 / 03$ through $6 / 30 / 04$ \\
\hline $\begin{array}{l}\text { Washington TRU Solutions (WTS) } \\
\text { 08-NT.01, WIPP Waste Information Data } \\
\text { Management Plan }\end{array}$ & $\begin{array}{l}\text { Rev. } 10,12 / 12 / 03 \\
\text { Rev. } 9,08 / 26 / 03\end{array}$ & $\begin{array}{l}\text { The specific changes being implemented by this revision are: provided additional clarification } \\
\text { that the operating record is maintained by Site Environmental Compliance; extensive revision to } \\
\text { provide additional clarification about functions performed by the WWIS Team; provided } \\
\text { additional clarification regarding QA oversight of the WWIS Software QA Program; re-formatted } \\
\text { section and provided additional clarifications, process description and details regarding data } \\
\text { management for Site Derived Waste. } \\
\text { The specific changes that were implemented by this revision are: the addition of new text that: } \\
\text { describes the functions performed by the WWIS System Operator; description of how the } \\
\text { change log captures information when container data is placed in a hold status or when } \\
\text { container data is reset to Pre-Submittal to Certification; description of the Overpack Container } \\
\text { Transportation Certification Document (OPTCD) that can be generated using e-TRAMPAC; } \\
\text { describes the interface with Waste Handling procedures and how container data for Site } \\
\text { Derived Waste is input to the WWIS by the Data Administrators; description of the fields for } \\
\text { "PCB Mass", "PCB Out-of-Service Date" and "PCB checkbox". It also includes a total re-write of } \\
\text { the Inventory Module description and Table 5, Data Fields for the Emplace Containers } \\
\text { Underground Data Entry Screen. }\end{array}$ \\
\hline $\begin{array}{l}\text { Washington TRU Solutions (WTS) } \\
\text { 08-NT.04 } \\
\text { WIPP Waste Information System } \\
\text { Configuration Management and Software } \\
\text { Quality Assurance Program Assurance }\end{array}$ & Rev. $6,03 / 17 / 04$ & $\begin{array}{l}\text { The specific changes being implemented by this revision are providing additional clarification } \\
\text { regarding development of Baseline Change Request (BCR) in the event that the budgets and } \\
\text { resources will not be adequate to support development and implementation of a revision(s) to } \\
\text { the WWIS client software. } \\
\text { The specific changes being implemented by this revision are providing clarifications throughout } \\
\text { the document and made several modifications to the WWIS Software Modification Request } \\
\text { Sheet, the WWIS Document Evaluation Sheet, and the WWIS Data Change Request Sheet. }\end{array}$ \\
\hline
\end{tabular}


Table 2: Procedure Revision Table

\begin{tabular}{|c|c|c|}
\hline Procedure & $\begin{array}{l}\text { Rev. \& Effective } \\
\text { Date }\end{array}$ & Description of Changes from $07 / 01 / 03$ through $6 / 30 / 04$ \\
\hline $\begin{array}{l}\text { Washington TRU Solutions (WTS) } \\
\text { 08-NT.09 WIPP Waste Information } \\
\text { System Security Plan }\end{array}$ & Rev. 0, 06/21/04 & $\begin{array}{l}\text { Formerly, security plans for the WWIS were developed, maintained and approved outside of the } \\
\text { Quality and Manufacturing Integrated System (QMIS). From a security standpoint, the WWIS is } \\
\text { categorized as mission essential and therefore requires an approved security plan. In order to } \\
\text { maintain adequate document control, management requested that the Security Plan for the } \\
\text { WWIS be available on QMIS. } \\
\text { The document provides the following information: identification of Information Processed (i.e., } \\
\text { what the WWIS does); identification of security personnel; a description of the WWIS and it's } \\
\text { use; responsibilities and expected behavior of the users (i.e., a summary of user categories } \\
\text { and privileges); application rules(i.e., limitations on changing data, rules for performing } \\
\text { searches, disseminating information, and a summary that describes how the software and } \\
\text { system hardware are changed), Contingency Plan that summarizes the ability to recover from } \\
\text { loss of existing application support with a requirement for annual testing of the contingency } \\
\text { plan; and technical security (i.e., use of security products and features, controls for users } \\
\text { identification, access controls, data validation controls, auditing, design review and application } \\
\text { testing, and software development. }\end{array}$ \\
\hline $\begin{array}{l}\text { Washington TRU Solutions (WTS) } \\
\text { 08-NT3020, TRU Waste Receipt }\end{array}$ & Rev. 9, 10/15/03 & $\begin{array}{l}\text { The revisions are to update the procedure to implement changes to receive PCB contaminated } \\
\text { waste and minor editorial changes. }\end{array}$ \\
\hline $\begin{array}{l}\text { Washington TRU Solutions (WTS) } \\
\text { 13-1, Washington TRU Solutions LLC } \\
\text { Quality Assurance Program }\end{array}$ & Rev. 24, 08/08/03 & The revisions were to reflect CBFO QAPD Revisions 4 and 5. \\
\hline
\end{tabular}




\title{
Table 3: Waste Emplacement Summary Report
}

\author{
July 1, 2003 through June 30, 2004
}


Table 3: Waste Emplacement Summary Report

\begin{tabular}{|c|c|c|c|c|}
\hline \multicolumn{5}{|c|}{ Summary of Waste Emplacement Inventory } \\
\hline \multicolumn{5}{|c|}{ TRU Waste Inventory } \\
\hline & \multicolumn{2}{|c|}{$\begin{array}{l}\text { Reporting Period }{ }^{1} \text { Emplaced } \\
\text { Container Volume }\left(\mathrm{m}^{3}\right)\end{array}$} & \multicolumn{2}{|c|}{$\begin{array}{l}\text { Cumulative Emplaced Container } \\
\text { Volume }\left(\mathrm{m}^{3}\right)\end{array}$} \\
\hline CH TRU & \multicolumn{2}{|c|}{8,693} & \multicolumn{2}{|c|}{21,646} \\
\hline \multicolumn{5}{|c|}{ Waste Components Inventory } \\
\hline & $\begin{array}{l}\text { Reporting } \\
\text { Period }^{1} \\
\text { Emplaced } \\
\text { Mass (kg) } \\
\end{array}$ & $\begin{array}{l}\text { Cumulative } \\
\text { Emplaced } \\
\text { Mass (kg) }\end{array}$ & $\begin{array}{c}\text { Maximum } \\
\text { Emplacement } \\
\text { Limiting Value } \\
(\mathrm{kg})\end{array}$ & $\begin{array}{l}\text { Percent of } \\
\text { Limiting Value }^{2} \\
\text { Emplaced }\end{array}$ \\
\hline \multirow{2}{*}{$\begin{array}{l}\text { Cellulose, } \\
\text { Plastic, } \\
\text { Rubber } \\
\text { Materials }^{3} \\
\end{array}$} & 550,342 & $1,850,273$ & $20,000,000$ & $9.25 \%$ \\
\hline & $\begin{array}{l}\text { Reporting } \\
\text { Period }^{1} \\
\text { Emplaced } \\
\text { Mass (kg) } \\
\end{array}$ & $\begin{array}{l}\text { Cumulative } \\
\text { Emplaced } \\
\text { Mass (kg) }\end{array}$ & $\begin{array}{c}\text { Minimum } \\
\text { Emplacement } \\
\text { Limiting Value } \\
(\mathrm{kg})\end{array}$ & $\begin{array}{l}\text { Percent of } \\
\text { Limiting Value } \\
\text { Emplaced }\end{array}$ \\
\hline Fe-Metals ${ }^{4}$ & $2,381,666$ & $6,405,350$ & $20,000,000$ & $32.03 \%$ \\
\hline $\begin{array}{l}\text { Non-Fe } \\
\text { Metals }\end{array}$ & 54,559 & 143,144 & 2,000 & $7157.20 \%$ \\
\hline $\begin{array}{l}\text { Residual } \\
\text { Liquids }\end{array}$ & \multicolumn{4}{|c|}{$\begin{array}{l}\text { Liquid waste is prohibited at WIPP. The total residual liquid in any payload } \\
\text { container shall not exceed one percent by volume of that payload container. }\end{array}$} \\
\hline
\end{tabular}

\begin{tabular}{|c|c|c|c|}
\hline \multicolumn{4}{|c|}{ Radiological Activity Inventory (curies) } \\
\hline Radionuclide & $\begin{array}{c}\text { Cumulative } \\
\text { Activity in FY } \\
2003 \text { Annual } \\
\text { Change Report }\end{array}$ & $\begin{array}{c}\text { Reporting } \\
\text { Period Activity }\end{array}$ & $\begin{array}{l}\text { Total Activity as } \\
\text { of June } 30,2004\end{array}$ \\
\hline${ }^{241} \mathrm{Am}$ & $1.22 E+05$ & 1.73E+04 & $1.40 \mathrm{E}+05$ \\
\hline${ }^{238} \mathrm{Pu}$ & $6.79 E+03$ & $3.68 E+03$ & $1.05 E+04$ \\
\hline${ }^{239} \mathrm{Pu}$ & 1.63E+05 & 4.30E+04 & $2.06 E+05$ \\
\hline${ }^{240} \mathrm{Pu}$ & $3.69 E+04$ & $1.20 E+04$ & $4.89 E+04$ \\
\hline${ }^{242} \mathrm{Pu}$ & $3.66 E+00$ & $3.11 E+00$ & $6.77 E+00$ \\
\hline${ }^{233} \mathrm{U}$ & 4.26E-01 & 7.24E-02 & 4.99E-01 \\
\hline${ }^{234} U$ & $2.39 E+00$ & 1.34E+00 & $3.73 E+00$ \\
\hline${ }^{238} \mathrm{U}$ & $8.00 E+00$ & 6.75E-01 & 8.67E+00 \\
\hline${ }^{137} \mathrm{Cs}$ & 6.16E-01 & 6.07E-01 & $1.22 E+00$ \\
\hline${ }^{90} \mathrm{Sr}$ & 7.53E-01 & 6.33E-01 & 1.39E+00 \\
\hline Total & 3.29E+05 & 7.60E+04 & 4.05E+05 \\
\hline
\end{tabular}

1. Reporting Period includes emplacement that occurred between 07/01/03 and 06/30/04

2. Limiting Value--Values from Docket A-93-02, II-B-2, CARD 24. These values are based on inventory assumptions and are not limited by the Land Withdrawal Act. These values may change as inventory destined for WIPP changes and the PA is updated.

3. Cellulose, plastic, rubber materials (CPR) includes container materials and CPR within the waste but does not include slip sheets or shrink wrap.

4. Fe-Metals includes both material in the waste and containers in total. 


\title{
Table 4: Performance Assessment Software and Hardware Changes
}

\author{
July 1, 2003 through June 30, 2004
}


Table 4: Performance Assessment Software and Hardware Changes

\begin{tabular}{|c|c|c|}
\hline $\begin{array}{l}\text { WIPP Use Codes/Software \& } \\
\text { Code Version }\end{array}$ & Version Date & Description of Changes from $7 / 1 / 03$ through 6/30/04 \\
\hline BRAGFLO Version 5.00 & $\begin{array}{l}03 / 23 / 04 \\
05 / 03 / 04\end{array}$ & $\begin{array}{l}\text { Regression Testing on OpenVMS V7.3-1/Compaq Alpha ES45 and } 8400 . \\
\text { Added Test Functionality. }\end{array}$ \\
\hline CAMCON_LIB Version 2.20 & $12 / 10 / 03$ & Regression Testing on OpenVMS V7.3-1/Compaq Alpha Server 8400. \\
\hline CAMDAT_LIB Version 1.25 & $12 / 10 / 03$ & Regression Testing on OpenVMS V7.3-1/Compaq Alpha Server 8400. \\
\hline CAMSUPES_LIB Version 2.22 & $12 / 10 / 03$ & Regression Testing on OpenVMS V7.3-1/Compaq Alpha Server 8400. \\
\hline $\begin{array}{l}\text { CCDFGF Version } 5.00 \\
\text { CCDFGF Version 5.00A } \\
\text { CCDFGF Version 5.00A }\end{array}$ & $\begin{array}{l}08 / 14 / 03 \\
09 / 10 / 03 \\
03 / 23 / 04\end{array}$ & $\begin{array}{l}\text { Revision to CCDFGF code consistent with results of Salado Flow peer review. } \\
\text { Corrected record length specification for output files. } \\
\text { Regression Testing on OpenVMS V7.3-1/Compaq Alpha ES45 and } 8400 .\end{array}$ \\
\hline CUTTINGS_S Version 5.10 & $10 / 24 / 03$ & Changed to implement DRSPALL results in PA. \\
\hline $\begin{array}{l}\text { DRSPALL Version } 1.00 \\
\text { DRSPALL Version } 1.10\end{array}$ & $\begin{array}{l}10 / 8 / 03,10 / 6 / 03 \\
02 / 18 / 04 \\
04 / 26 / 04 \\
04 / 26 / 04 \\
04 / 26 / 04\end{array}$ & $\begin{array}{l}\text { Implementation of new conceptual model for Spallings. } \\
\text { Implement Input Parameter Bounds Checking. } \\
\text { Regression Testing on OpenVMS V7.3-1/Compaq Alpha ES45 and } 8400 . \\
\text { Bounds checking changes and cosmetic changes. } \\
\text { Regression Testing on OpenVMS V7.3-1/Compaq Alpha ES45 and } 8400 .\end{array}$ \\
\hline EPAUNI Version 1.15A & $\begin{array}{l}07 / 8 / 03 \\
03 / 22 / 04\end{array}$ & $\begin{array}{l}\text { Change definition of IFLAG to allow change in inventory base year. } \\
\text { Regression Testing on OpenVMS V7.3-1/Compaq Alpha ES45 and } 8400 .\end{array}$ \\
\hline GENII-A Version 2.10 & $05 / 05 / 04$ & Regression Testing on OpenVMS V7.3-1/Compaq Alpha ES45 and 8400. \\
\hline ORIGEN2 Version 2.2 & $11 / 4 / 03$ & Moved from LANL to SNL on Dell Precision $340,2.26 \mathrm{GHz}, 523 \mathrm{Mb}$ RAM. \\
\hline PANEL Version 4.02 & $03 / 23 / 04$ & Regression Testing on OpenVMS V7.3-1/Compaq Alpha ES45 and 8400. \\
\hline PLT_LIB Version 2.04 & $12 / 9 / 03$ & $\begin{array}{l}\text { Regression Testing on OpenVMS V7.3-1/Compaq Alpha Server ES40, ES45, and } 8400 \text { and } \\
\text { corrected postscript and changed logarithmic axis. }\end{array}$ \\
\hline
\end{tabular}


Table 4: Performance Assessment Software and Hardware Changes

\begin{tabular}{|c|c|c|}
\hline $\begin{array}{l}\text { WIPP Use Codes/Software \& } \\
\text { Code Version }\end{array}$ & Version Date & Description of Changes from 7/1/03 through 6/30/04 \\
\hline PREBRAG Version 7.0 & $03 / 23 / 04$ & Regression Testing on OpenVMS V7.3-1/Compaq Alpha ES45 and 8400. \\
\hline $\begin{array}{l}\text { PRECCDFGF Version 1.00A } \\
\text { PRECCDFGF Version 1.00B } \\
\text { PRECCDFGF Version 1.00C }\end{array}$ & $\begin{array}{l}08 / 6 / 03 \\
06 / 10 / 04 \\
09 / 10 / 03 \\
03 / 23 / 04 \\
10 / 13 / 03 \\
06 / 10 / 04\end{array}$ & $\begin{array}{l}\text { Change to data for Test Case } 1 \text { and corrected incorrect write statement. } \\
\text { Retired from use. } \\
\text { Corrected material names and added RECL=1610. } \\
\text { Regression Testing on OpenVMS V7.3-1/Compaq Alpha ES45 and } 8400 . \\
\text { Corrected average radionuclide concentrations for Spallings. } \\
\text { Retired from use. }\end{array}$ \\
\hline PREGENII Version 6.30 & $05 / 06 / 04$ & Regression Testing on OpenVMS V7.3-1/Compaq Alpha ES45 and 8400. \\
\hline POSTGENII Version 4.20 & $05 / 10 / 04$ & Regression Testing on OpenVMS V7.3-1/Compaq Alpha ES45 and 8400. \\
\hline SANTOS Version 2.1.7 & $08 / 25 / 03$ & Moved to new platform and revalidated on Compaq Alpha 8400 with Tru64 OSF1V5.1. \\
\hline SDBREAD_LIB Version 3.11 & 08/18/03, 12/10/03 & Regression Testing on OpenVMS V7.3-1/Compaq Alpha Server ES40, ES45, and 8400. \\
\hline SECOTP2D Version 1.41A & $\begin{array}{l}07 / 9 / 03 \\
03 / 23 / 04\end{array}$ & $\begin{array}{l}\text { Change dimension of MAXK for larger grid used in CRA. } \\
\text { Regression Testing on OpenVMS V7.3-1/Compaq Alpha ES40 and } 8400 .\end{array}$ \\
\hline TWBID Version 3.12 & $\begin{array}{l}08 / 12 / 03 \\
11 / 4 / 03\end{array}$ & $\begin{array}{l}\text { Corrected data errors. } \\
\text { Moved from LANL to SNL on Dell Precision } 340,2.26 \mathrm{GHz}, 523 \mathrm{Mb} \text { RAM. }\end{array}$ \\
\hline
\end{tabular}




\section{Summary}

The DOE believes the changes reported in this Annual Change Report do not represent significant changes pertaining to the disposal system.

\section{Reports Referenced in and Provided with this Report}

Delaware Basin Monitoring Annual Report, DOE/WIPP 99-2308, Revision 4, September 2003.

Geotechnical Analysis Report for July 2002 - June 2003, DOE/WIPP 04-3177, Volumes 1 \& 2, March 2004.

Sandia National Laboratories Annual Compliance Monitoring Parameter Assessment for 2003, Revision 1, June 2004.

Waste Isolation Pilot Plant Site Environmental Report Calendar Year 2002, DOE/WIPP 03-2225, September 2003.

Waste Isolation Pilot Plant Subsidence Monument Leveling Survey 2003, DOE/WIPP 04-2293, October 2003. 